\title{
PENGARUH PENDAPATAN ASLI DAERAH DAN PENDAPATAN TRANSFER TERHADAP HUBUNGAN ANTARA BELANJA MODAL DENGAN BELANJA PEMELIHARAAN DALAM ANGGARAN DAERAH
}

\author{
Mochammad Solichin \\ Universitas Teknologi Yogyakarta \\ mcsol_iqqin@yahoo.com
}

\section{ABSTRACT}

\begin{abstract}
Objective of this study is to empirically test whether local original income and transfer revenue give influence to the relation between capital expenditure and maintenance expenditure in regional government budget. First test showed that real local original income give positive effect toward this relation in present year and maintenance expenditure in next year. This result shows that real local original income is considered variable by local government in arranging budget of maintenance in relation with capital expenditure policy. Second test showed that transfer revenue have no positive effect to the relationship between present year capital expenditure and maintenance expenditure in next year. This result explaining that transfer revenue is not considered variable during determination of next year maintenance expenditure by local government in relation with present year capital expenditure. This study give empiric evidence of flypaper effect in relation between revenue and regional budget, which suggests that people tend to be effectively spend their revenue that comes from their own effort, than income from other party.
\end{abstract}

Keywords: real local original income, transfer revenue, capital expenditure, maintenance expenditure, local government, flypaper effect.

\section{PENDAHULUAN}

Manajemen keuangan pemerintah daerah di Indonesia memasuki era baru seiring dengan diberlakukannya kebijakan otonomi daerah. Kebijakan tersebut tertuang dalam UU No. 22 tahun 1999 tentang Pemerintahan Daerah dan UU No 25 tahun 1999 tentang Perimbangan Keuangan antara Pemerintah Pusat dan Daerah efektif diberlakukan per Januari tahun 2001 (UU ini dalam perkembangannya diperbarui dengan dikeluarkannya UU No.32 tahun 2004 dan UU No. 33 tahun 2004). Undang-undang ini memberikan peluang bagi daerah untuk menggali potensi daerah yang dimiliki dan meningkatkan
\end{abstract}

kinerja keuangannya dalam rangka mewujudkan kemandirian daerah.

Dalam era otonomi daerah atau desentralisasi fiskal diharapkan terjadinya peningkatan pelayanan di berbagai sektor terutama sektor publik. Peningkatan layanan publik ini diharapkan dapat meningkatkan daya tarik bagi investor untuk membuka usaha di daerah. Harapan ini tentu saja dapat terwujud apabila ada upaya serius (pemerintah) dengan memberikan berbagai fasilitas pendukung (investasi). Konsekuensinya, pemerintah perlu untuk memberikan alokasi belanja yang lebih besar untuk tujuan ini. Desentralisasi fiskal di satu sisi memberikan kewenangan 
yang lebih besar dalam pengelolaan daerah, tetapi di sisi lain memunculkan persoalan baru, dikarenakan tingkat kesiapan fiskal daerah yang berbeda-beda. Penelitian yang dilakukan Adi (2005) menunjukkan terjadi disparitas pertumbuhan ekonomi yang cukup tinggi antar daerah (kabupaten dan kota) dalam pelaksanaan desentralisasi fiskal. Nanga (2005) mengindikasikan terjadinya ketimpangan fiskal antar daerah dan bisa jadi hal ini mempengaruhi tingkat pertumbuhan ekonomi daerah.

Penerapan desentralisasi fiskal oleh pemerintah pusat Indonesia memiliki tujuan untuk kemandirian pemerintah daerah dalam pengelolaan rumah tangganya. Dalam penerapannya pemerintah pusat tidak lepas tangan secara penuh dan masih memberikan bantuan kepada pemerintah daerah berupa dana perimbangan yang dapat digunakan oleh pemerintah daerah dalam pembangunan dan menjadi komponen pendapatan daerah dalam APBD. Pemerintah daerah harus dapat menjalankan rumah tangganya secara mandiri dan dalam upaya peningkatan kemandirian ini, pemerintah dituntut untuk meningkatkan pelayanan publiknya. Oleh karena itu, anggaran belanja daerah akan tidak logis jika proporsi anggarannya lebih banyak untuk belanja rutin (Abimanyu, 2005). Belanja Modal yang dilakukan oleh pemerintah daerah di antaranya pembangunan dan perbaikan sektor pendidikan, kesehatan, transportasi, sehingga masyarakat juga menikmati manfaat dari pembangunan daerah. Tersedianya infrastruktur yang baik diharapkan dapat menciptakan efisiensi dan efektifitas di berbagai sektor, produktifitas masyarakat diharapkan menjadi semakin tinggi dan pada gilirannya terjadi peningkatan pertumbuhan ekonomi.

Pembangunan dalam sektor pelayanan kepada publik akan merangsang masyarakat untuk lebih aktif dan bergairah dalam bekerja karena ditunjang oleh fasilitas yang memadai selain itu investor juga akan tertarik kepada daerah karena fasilitas yang diberikan oleh daerah. Dengan bertambahnya produktivitas masyarakat dan investor yang berada di daerah akan berdampak pada peningkatan pendapatan asli daerah. Pendapatan asli daerah yang semakin tinggi akan merangsang pemerintah daerah untuk lebih meningkatkan mutu pelayanannya kepada publik sehingga tingkat pertumbuhan ekonomi daerah akan meningkat seiring dengan meningkatnya pendapatan per kapita.

Pelaksanaan otonomi daerah di Indonesia sejak tahun 2001 berimplikasi pada perubahan dalam sistem pembuatan keputusan terkait dengan pengalokasian sumberdaya dalam anggaran pemerintah daerah. Sebelumnya penentuan alokasi ditentukan oleh Pemerintah Pusat dengan mengacu pada realisasi anggaran tahun sebelumnya dengan sedikit peningkatan tanpa merubah jenis atau pos belanja. Sistem ini disebut sistem anggaran berimbang dan dinamis. Setelah otonomi daerah, tepatnya pada tahun 2003, pendekatan anggaran yang digunakan adalah anggaran berbasis kinerja. Selain itu, peran Dewan Perwakilan Rakyat Daerah (DPRD) sebagai legilsatif daerah semakin besar sehingga dapat menjadi instrumen untuk dilaksanakannya checks and balances dalam pelaksanaan pemerintahan daerah.

Dari aspek regulasi, Peraturan Pemerintah (PP) No. 58/2005 dan Peraturan Menteri Dalam Negeri (Permendagri) No. 13/2006 (telah direvisi dengan Permendagri No. 59/2007) memberikan penegasan bahwa daerah memiliki kewenangan untuk menentukan alokasi sumberdaya ke dalam belanja-belanja dengan menganut asas kepatutan, kebutuhan, dan kemampuan daerah. Pemerintah daerah, bekerjasama dengan DPRD, terlebih dahulu menentukan kebijakan umum anggaran (KUA) dan prioritas plafon anggaran sementara (PPAS) sebagai arahan dalam pengalokasian sumberdaya dalam APBD. KUA dan PPAS merupakan pedoman yang merupakan hasil penjaringan aspirasi masyarakat sehingga 
diperoleh gambaran yang cukup tentang kebijakan jangka pendek dan kebijakan jangka panjang yang berkaitan dengan kebijakan pengelolaan keuangan daerah.

Alokasi sumber daya ke dalam anggaran belanja modal merupakan sebuah proses yang sarat dengan kepentingan-kepentingan politis serta membutuhkan kajian-kajian mendalam. Selain nilainya besar, anggaran belanja modal berkaitan dengan spesifikasi dan sumber pembiayaan dalam jangka panjang (Bland \& Nunn, 1992). Anggaran ini sebenarnya dimaksudkan untuk memenuhi kebutuhan publik akan sarana dan prasarana umum yang diberikan secara cuma-cuma oleh pemerintah daerah. Namun, adanya kepentingan politik dari lembaga legislatif yang terlibat dalam proses penyusunan anggaran menyebabkan alokasi belanja modal menjadi terdistorsi dan sering tidak efektif dalam memecahkan permasalahan di masyarakat (Keefer \& Khemani, 2003; Ablo \& Reinikka, 1998).

Pengalokasian belanja modal sangat berkaitan dengan pengeluaran untuk pemeliharaan aset tetap yang dihasilkan dari belanja modal tersebut. Konsep kerangka pengeluaran jangka panjang menyatakan bahwa kebijakan belanja modal harus memperhatikan kemanfaatan (usefulness) dan kemampuan keuangan pemerintah daerah (budget capability) dalam pengelolaan aset tersebut dalam jangka panjang (Allen dan Tommasi, 2001).

Penelitian yang menguji pengaruh belanja modal terhadap belanja pemeliharaan telah banyak dilakukan. Namun menunjukkan hasil yang tidak dapat disimpulkan secara konklusif. Hal tersebut terjadi karena hasil yang mereka kemukakan belum konsisten dan sering terjadi kontradiksi antara satu peneliti dengan peneliti yang lain.

Penelitian ini akan menganalisis pengaruh belanja modal terhadap belanja pemeliharaan dalam anggaran pemerintah daerah dengan menggunakan variabel pendapatan asli daerah dan pendapatan transfer sebagai variabel pemoderasi.

Berdasarkan uraian tersebut, dapat dirumuskan permasalahan sebagai berikut: (1) Apakah hubungan antara belanja modal tahun berjalan dengan belanja pemeliharaan tahun berikutnya dimoderasi oleh pendapatan asli daerah, (2) Apakah hubungan antara belanja modal tahun berjalan dengan belanja pemeliharaan tahun berikutnya dimoderasi oleh pendapatan transfer.

\section{REVIEW LITERATUR DAN HIPOTESIS \\ Hubungan Belanja Modal Dengan Belanja Pemeliharaan Pemerintah Kabupaten/Kota}

Apabila suatu organisasi mengambil suatu kebijakan untuk melakukan belanja modal, maka biasanya akan memiliki dampak kepada belanja pemeliharaan ke depan. Bland dan Nunn (1992) menyatakan bahwa capital outlays memiliki implikasi positif yang tidak ambigu terhadap operasi di masa yang akan datang. Mereka menemukan bahwa 5 dari 6 layanan municipal yang tersedia dipengaruhi oleh belanja modal di masa yang lampau, khususnya pada anggaran operasional kepolisian dan pemadam kebakaran. Namun ada sebagian peneliti menyatakan bahwa belanja modal tidak selalu berhubungan dengan belanja operasional. Pagano (1984) menemukan bahwa pemerintahan kota dan pemerintahan lokal selalu membuat anggaran yang terpisah untuk anggaran operasional dan anggaran modal.

Hasil survey pada National League of Cities menemukan bahwa 57 persen kota tidak mempertimbangkan "tindakan pencegahan" terhadap pemeliharaan dan biaya-biaya perbaikan dari suatu proyek (Kamensky, 1984). Thomassen (1990) memperkirakan setengah dari state melaporkan tidak berhasil menghubungkan antara capital dan non-capital pada anggaran mereka, sehingga hal tersebut menunjukkan adanya kemungkinan pengeluaran untuk belanja modal berbeda dengan belanja lainnya. 
Dari uraian di atas, apabila pemerintahan mengambil suatu kebijakan pada belanja modal, maka hal tersebut kemungkinan berpengaruh terhadap anggaran pemeliharaan pemerintah itu sendiri. Penelitian yang menguji pengaruh belanja modal terhadap belanja pemeliharaan telah banyak dilakukan. Namun menunjukkan hasil yang tidak dapat disimpulkan secara konklusif. Hal tersebut terjadi karena hasil yang mereka kemukakan belum konsisten dan sering terjadi kontradiksi antara satu peneliti dengan peneliti yang lain. Menurut Govindarajan(1986), untuk menyelesaikan perbedaan dari hasil penelitian tersebut, dapat dilakukan dengan pendekatan kontinjensi (contingency approach). Pendekatan ini memberikan gagasan bahwa sifat hubungan antara belanja modal dengan belanja pemeliharaan mungkin berbeda satu situasi dengan situasi yang lain. Pendekatan ini secara sistematis mengevaluasi berbagai kondisi atau variabel yang dapat mempengaruhi hubungan antara belanja modal dengan belanja pemeliharaan.

Hipotesis pertama yang akan diuji akan menggunakan variabel pemoderasi pendapatan asli daerah. Variabel pendapatan asli daerah diduga menjadi faktor yang akan mempegarui hubungan antara belanja modal dengan belanja pemeliharaan. Infrastruktur dan sarana prasarana yang ada di daerah akan berdampak pada pertumbuh ekonomi daerah. Jika sarana dan prasarana memadai maka masyarakat dapat melakukan aktivitas sehari - harinya secara aman dan nyaman yang akan berpengaruh pada tingkat produktivitasnya yang semakin meningkat, dan dengan adanya infrastruktur yang memadai akan menarik investor untuk membuka usaha di daerah tersebut. Dengan bertambahnya belanja modal maka akan berdampak pada periode yang akan datang yaitu produktivitas masyarakat meningkat dan bertambahnya investor akan meningkatkan pendapatan asli daerah (Abimanyu, 2005).
Peningkatan Pemerintah Daerah dalam investasi modal (belanja modal) diharapkan mampu meningkatkan kualitas layanan publik dan pada gilirannya mampu meningkatkan tingkat partisipasi (kontribusi) publik terhadap pembangunan yang tercermin dari adanya peningkatan PAD (Mardiasmo, 2002). Wong (2004) menunjukkan bahwa pembangunan infrastruktur industri mempunyai dampak yang nyata terhadap kenaikan pajak daerah. Dalam penelitian Adi (2006) menyatakan bahwa belanja modal memberikan dampak yang positif dan signifikan terhadap Pendapatan Asli Daerah. Dengan kata lain, pembangunan berbagai fasilitas sektor publik akan berujung pada peningkatan pendapatan daerah. Dalam penerapan desentralisasi, pembangunan menjadi prioritas utama pemerintah daerah untuk menunjang peningkatan PAD. Penelitan yang dilakukan oleh Abdullah dan Halim (2003) menunjukkan adanya pengaruh yang kuat belanja daerah terhadap peningkatan pendapatan asli daerah.

Dari uraian tersebut dapat dirumuskan hipotesis sebagai berikut:

$H_{1}$ : Pendapatan asli daerah dan belanja modal tahun berjalan berpengaruh terhadap belanja pemeliharaan tahun berikutnya.

\section{Pengaruh Pendapatan Daerah Terhadap Hubungan Antara Belanja Modal Dengan Belanja Pemeliharaan}

Peningkatan investasi modal (belanja modal) oleh Pemerintah Daerah diharapkan mampu meningkatkan kualitas layanan publik dan pada gilirannya mampu meningkatkan tingkat partisipasi (kontribusi) publik terhadap pembangunan yang tercermin dari adanya peningkatan PAD (Mardiasmo, 2002). Wong (2004) menunjukkan bahwa pembangunan infrastruktur industri mempunyai dampak yang nyata terhadap kenaikan pajak daerah. Dalam penelitian Adi (2006) menyatakan bahwa belanja 
modal memberikan dampak yang positif dan signifikan terhadap Pendapatan Asli Daerah. Dengan kata lain, pembangunan berbagai fasilitas sektor publik akan berujung pada peningkatan pendapatan daerah. Dalam penerapan desentralisasi, pembangunan menjadi prioritas utama pemerintah daerah untuk menunjang peningkatan PAD. Penelitan yang dilakukan oleh Abdullah dan Halim (2003) menunjukkan adanya pengaruh yang kuat belanja daerah terhadap peningkatan pendapatan asli daerah.

Dalam literatur ekonomi dan keuangan daerah, hubungan pendapatan dan belanja daerah didiskusikan secara luas sejak akhir dekade 1950an dan berbagai hipotesis tentang hubungan diuji secara empiris (Chang \& Ho, 2002). Holtz-Eakin et al (1985) menyatakan bahwa terdapat keterkaitan sangat erat antara transfer dari pemerintah pusat dengan belanja pemerintah daerah. Studi Legrensi dan Milas (2001), menggunakan sampel municipalities di Italia, menemukan bukti empiris bahwa dalam jangka panjang transfer berpengaruh terhadap belanja daerah. Secara spesifik mereka menegaskan bahwa variabelvariabel kebijakan pemda dalam jangka pendek disesuaikan (adjusted) dengan transfer yang diterima, sehingga memungkinkan terjadinya respon yang non-linier dan asymmetric.

Gamkhar dan Oates (1996) menganalisis respon pemerintah daerah terhadap perubahan jumlah transfer dari pemerintah federal di Amerika Serikat untuk tahun 1953-1991. Mereka menyatakan bahwa pengurangan jumlah transfer (cut in the federal grants) menyebabkan penurunan dalam pengeluaran daerah. Studi Holtz dan Eakin et al (1994) menganalisis model maximizing under uncertainty of intertemporal utility function dengan menggunakan data runtun waktu selama tahun 1934-1991 untuk mengetahui seberapa jauh pengeluaran daerah dapat dirasionalkan melaui suatu model, di mana keputusan-keputusan didasarkan pada ketersediaan sumber daya secara permanen, bukan ketersediaan yang sifatnya temporer. Mereka menemukan bahwa semua current spending ditentukan oleh current resources. Hal tersebut tidak berbeda dengan hasil penelitian Sukri \& Halim (2004).

Sejak diterapkannya desentralisasi fiskal dengan semangat otonomi daerah, pemerintah pusat mengharapkan daerah dapat mengelola sumber daya yang dimiliki sehingga tidak hanya mengandalkan dana transfer. Di beberapa daerah peran dana transfer sangat signifikan karena kebijakan belanja daerah lebih didominasi oleh jumlah dana transfer dari pada pendapatan asli daerah (Sidik et al, 2002). Setiap dana transfer yang diterima daerah akan ditunjukkan untuk belanja pemerintah daerah, maka tidak jarang apabila pemerintah daerah menetapkan rencana pendapatan daerah secara pesimis dan rencana belanja cenderung optimis supaya transfer yang diterima daerah lebih besar.

Dalam penelitiannya Holtz-Eakin et al (1994) menyatakan terhadap keterkaitan sangat erat antara transfer dari pemerintah pusat dengan belanja modal. Pada studi yang dilakukan oleh Legrenzi \& Milas (2001) dalam Abdullah dan Halim (2003) menemukan bukti empiris bawasanya dalam jangka panjang transfer berpengaruh terhadap belanja modal dan pengurangan jumlah transfer dapat menyebabkan penurunan dalam pengeluaran belanja modal. Prakoso (2004) memperoleh temuan empiris yang sama yang menunjukkan bahwa jumlah belanja modal dipengaruhi oleh dana alokasi umum yang diterima dari pemerintah pusat.

Berdasarkan hasil-hasil penelitian yang disebutkan di atas, dan secara empiris penelitian yang menguji pengaruh belanja modal terhadap belanja pemeliharaan menghasilkan temuan yang tidak konsisten, maka diduga terdapat variabel lain dalam hal ini adalah pendapatan daerah yang mempengaruhi hubungan antara belanja modal dengan belanja pemeliharaan. Selanjutnya secara empiris juga ditemukan adanya flypaper 
effect dalam hubungan pendapatan dengan belanja (Moisio, 2002) yang menyatakan bahwa orang akan lebih hemat dalam membelanjakan pendapatan yang merupakan hasil dari effortnya sendiri dibanding pendapatan yang diberikan pihak lain (seperti grants atau transfer). Temuan Moisio (2002) tersebut mengindikasikan bahwa terdapat perbedaan karakteristik dari jenis pendapatan daerah yaitu pendapatan asli daerah dan pendapatan transfer. Penelitian yang menguji hubungan antara belanja modal dan belanja pemeliharaan belum ada yang menggunakan lag atau perbedaan tahun observasi. Artinya, data yang dianalisis adalah data cross-sectional, yakni data untuk mengukur variabel terikat bersumber dari tahun yang sama dengan data untuk mengukur variabel bebas. Untuk analisis yang lebih mendalam diperlukan data lag untuk mengetahui pengaruh belanja modal terhadap belanja pemeliharaan tahun selanjutnya. Dari uraian tersebut dapat dirumuskan hipotesis sebagai berikut:

$\mathrm{H}_{2}$ : Pendapatan Transfer dan Belanja Modal tahun berjalan berpengaruh positif terhadap belanja pemeliharaan tahun berikutnya.

\section{METODE PENELITIAN}

\section{Sampel dan Data Penelitian}

Sampel yang digunakan dalam penelitian ini adalah pemerintah kabupaten dan kota yang telah menyajikan laporan keuangan khususnya laporan realisasi APBD sesuai dengan dengan ketentuan yang berlaku.

Data dalam penelitian ini adalah data keuangan daerah Kabupaten/Kota berupa realisasi APBD untuk tahun 2005 dan 2006 yang diterbitkan oleh Badan Pusat Statistik serta situs pemerintah daerah di http://www.sikd.djapk. go.id/. Data realisasi APBD yang digunakan adalah data pendapatan asli daerah, dana transfer, belanja pemeliharaan serta data belanja modal setiap sampel kabupaten/kota.

\section{Definisi Operasional Variabel-Variabel Penelitian}

Variabel bebas dalam studi ini adalah realisasi Pendapatan Asli Daerah tahun ke-n, pendapatan transfer tahun ke-n, dan belanja modal tahun ke-n. Sedangkan variabel terikatnya adalah realisasi belanja pemeliharaan tahun $n+1$.

\section{Metode Analisis}

Analisis data dilakukan dengan menggunakan statistik parametrik yaitu analisis regresi ganda. Untuk menguji hipotesis (H1 dan $\mathrm{H} 2)$ menggunakan Moderated Regression Analysis (MRA) dengan menggunakan model interaksi (interaction). Model persamaan regresi pada studi ini merupakan persamaan regresi yang pernah digunakan oleh beberapa peneliti terdahulu, antara lain (Dunk, 1993; Nouri, H, 1994, dan Nouri et al., 1996). Hipotesis pertama akan diuji dengan persamaan regresi:

$\mathrm{Y}_{\mathrm{a} . \mathrm{i}}=\beta_{0}+\beta_{1} \mathrm{BM}+\beta_{2} \mathrm{PAD}+\beta_{3} \mathrm{BM}^{*} \mathrm{PAD}+\mathrm{e}$ dimana,

$Y \quad$ : anggaran belanja pemeliharaan

$\beta_{0} \quad$ : konstanta

$\mathrm{BM}$ : realisasi belanja modal

PAD : Pendapatan Asli Daerah

$e \quad$ : kesalahan estimasi.

Model penelitian pengaruh Pendapatan Asli Daerah dan Belanja Modal Tahun Berjalan terhadap Belanja Pemeliharaan tahun selanjutnya pemerintah Kabupaten/Kota di Indonesia dapat digambarkan sebagai berikut:

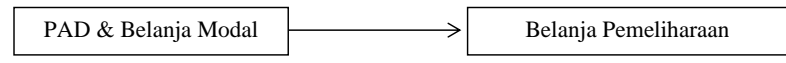

Dalam pengujian hipotesis di atas, dilakukan dengan melihat hasil perhitungan statistik dengan menggunakan Moderated Regression Analysis (MRA). Karena digunakan interaksi variabel, maka cara membacanya harus juga hati-hati. Analisis statistis yang dilakukan adalah dengan melihat signifikansinya ( $p$-val), koefisien regresi, dan koefisien determinasinya. 
Jika hasil pengujian ternyata $\beta_{3}$ adalah signifikan dan $\beta_{2}$ tidak signifikan, maka berarti variabel $\beta_{2}$ tersebut memang merupakan variabel kontijensi (pemoderasi) hubungan antara Y (belanja pemeliharaan) dan X1 (belanja modal). Misalnya $p$-val untuk $\beta_{3}$ signifikan maka berarti hipotesis tersebut gagal ditolak atau dengan kata lain bahwa interaksi antara pendapatan asli daerah dengan belanja modal memang berpengaruh terhadap belanja pemeliharaan. Sementara itu, untuk melihat apakah pengaruh tersebut positif atau negatif maka didasarkan pada koefisien regresinya, apakah nilai negatif (-) atau positif $(+)$. Apabila ternyata koefisien regresi tersebut positif $(+)$, maka dapat dikatakan bahwa interaksi dua variabel tersebut memang berhubungan secara positif dengan belanja pemeliharaan.

Sedangkan hipotesis kedua akan diuji dengan persamaan regresi:

$$
\mathrm{Y}_{\mathrm{a} . \mathrm{i}}=\beta_{0}+\beta_{1} \mathrm{BM}+\beta_{2} \mathrm{TR}+\beta_{3} \mathrm{BM}^{*} \mathrm{TR}+\mathrm{e}
$$

dimana,

$$
\begin{array}{ll}
Y & : \text { anggaran belanja pemeliharaan } \\
\beta_{0} & \text { : konstanta } \\
\text { BM } & \text { : realisasi belanja modal } \\
\text { TR } & \text { : Pendapatan Transfer } \\
e & \text { : kesalahan estimasi. } \\
\text { Model } & \text { penelitian pengaruh Pendapatan }
\end{array}
$$
Transfer dan Belanja Modal Tahun Berjalan terhadap Belanja Pemeliharaan tahun selanjutnya pemerintah Kabupaten/Kota di Indonesia dapat digambarkan sebagai berikut:

HASIL PENELITIAN DAN PEMBAHASAN

Pengaruh Pendapatan Asli Daerah Terhadap Hubungan Antara Belanja Modal Tahun Berjalan Dengan Belanja Pemeliharaan Tahun Berikutnya

Pengujian untuk melihat apakah pendapatan asli daerah mempengaruhi hubungan antara belanja modal dengan belanja pemeliharaan tahun berikutnya dilakukan dengan menggunakan model regresi Moderated Regression Analysis dengan menggunakan model interaksi. Hasil regresi tersebut dapat dilihat pada tabel 1 berikut ini:

\section{Tabel 1}

Model Summary

\begin{tabular}{|l|r|r|r|r|}
\multicolumn{7}{c|}{ Model Summary } \\
\hline Model & R & R Square & $\begin{array}{c}\text { Adjusted } \\
\text { R Square }\end{array}$ & $\begin{array}{c}\text { Std. Error of } \\
\text { the Estimate }\end{array}$ \\
\hline 1 &, $520 \mathrm{a}$ &, 270 &, 231 & 21630,23635 \\
\hline
\end{tabular}

a. Predictors: (Constant), PAD*BM, Belanja Modal, PAD

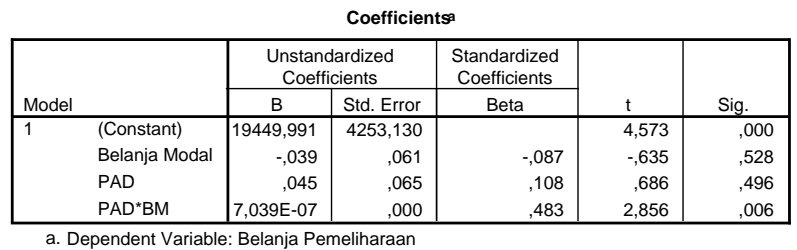

Sumber: hasil olah data

Dari tabel di atas terlihat nilai $\mathrm{t}$ statistic untuk varibel interaksi Pendapatan Asli Daerah dengan Belanja Modal signifikan sebesar 0,006 sedangkan $\mathrm{t}$ statistic untuk pendapatan asli daerah tidak signifikan sebesar 0,496. Hal ini berarti bahwa pendapatan asli daerah berpengaruh signifikan positif terhadap hubungan antara belanja modal dengan belanja pemeliharaan tahun berikutnya. Sehingga hipotesis pertama yang menyatakan pendapatan asli daerah berpengaruh terhadap hubungan antara belanja modal tahun berjalan dengan belanja pemeliharaan tahun berikutnya tidak dapat ditolak. Artinya Pendapatan asli daerah merupakan variabel yang dipertimbangkan oleh pemerintah daerah pada saat menyusun besaran anggaran pemeliharaan terkait dengan kebijakan belanja modal yang telah ditentukan.

Temuan ini menunjukkan bahwa untuk alokasi belanja fisik yang dibuat oleh pemerintah daerah mempertimbangkan pendapatan asli daerahnya yang pada akhirnya berdampak terhadap alokasi belanja pemeliharaan. Beberapa penelitian juga menemukan bahwa 
untuk pembiayaan belanja non rutin (nonrecurrent expenditures) dibuat kebijakan spesifik berdasarkan sumber daya. Misalnya pembangunan jalan raya bersumber dari pajak kendaraan bermotor dan pajak bahan bakar, pembangunan fasilitas kesehatan bersumber dari retribusi atas pelayanan kesehatan yang diberikan oleh pemerintah (service charges). Pembiayaan seperti ini tidak berlaku untuk belanja-belanja rutin (Moisio, 2002).

Pengalokasian belanja modal sangat berkaitan dengan pembiayaan untuk pemeliharaan aset tetap yang dihasilkan dari belanja modal tersebut. Konsep multi-term expenditure framework (MTEF) menyatakan bahwa kebijakan belanja modal harus memperhatikan kemanfaatan (usefulness) dan kemampuan keuangan pemerintah daerah (budget capability) dalam pengelolaan aset tersebut dalam jangka panjang (Allen dan Tommasi, 2001). Dalam kontek keuangan daerah, pendapatan asli daerah sebagai sumber pendanaan dalam anggaran daerah akan menentukan besaran alokasi anggaran belanja pemeliharaan kaitannya dengan kebijakan anggaran belanja modalnya. Hal ini terjadi karena karakteristik pendapatan asli daerah yang memerlukan sumber dana untuk mendapatkannya sehingga daerah cenderung hati-hati dalam pemanfaatannya.

Dari beberapa wawancara yang telah peneliti lakukan dengan praktisi (pelaku) keuangan daerah diperoleh kesimpulan yang mendukung temuan di atas. Para praktisi keuangan daerah merasa bahwa sejak diberlakukannya Undang-Undang Otonomi Daerah Nomor 22 Tahun 1999 dan Undang-Undang Nomor. 25 Tahun 1999 mengenai Perimbangan Keuangan antara Pemerintah Pusat dan Daerah secara langsung merubah proses pembangunan regional dari berorientasi nasional ke daerah. Perubahan ini membawa konsekuensi pada program pembangunan sektoral dan daerah. Oleh karena itu pemerintah daerah diarahkan untuk dapat menjadi mandiri. Perubahan ini secara ringkas tentunya menyebabkan adanya perubahan mendasar dalam mengelola keuangan daerah.

Secara praktis, kemandirian daerah dilandasi oleh kemampuan pengelolaan segala sumberdaya yang dimiliki, baik yang berupa tangible, intangible maupun yang very intangible. Salah satu sumber pendanaan penting yang dapat mencerminkan kemampuan kemandirian suatu daerah dalam mengelola daerahnya disebutkan sebagai Pendapatan Asli Daerah (PAD). Tingkat PAD yang tinggi menunjukkan daerah akan semakin mandiri dalam memberikan pelayanan kepada masyarakat di antaranya terlihat dalam alokasi besaran anggaran belanja modal yang tentunya berdampak pada belanja pemeliharaannya.

\section{Pengaruh Pendapatan Transfer Terhadap Hubungan Antara Belanja Modal Tahun Berjalan dengan Belanja Pemeliharaan Tahun Berikutnya}

Model regresi interaksi juga digunakan untuk menguji hipotesis yang kedua. Hasil regresi untuk hipotesis yang kedua dapat terlihat dalam tabel 2 berikut ini:

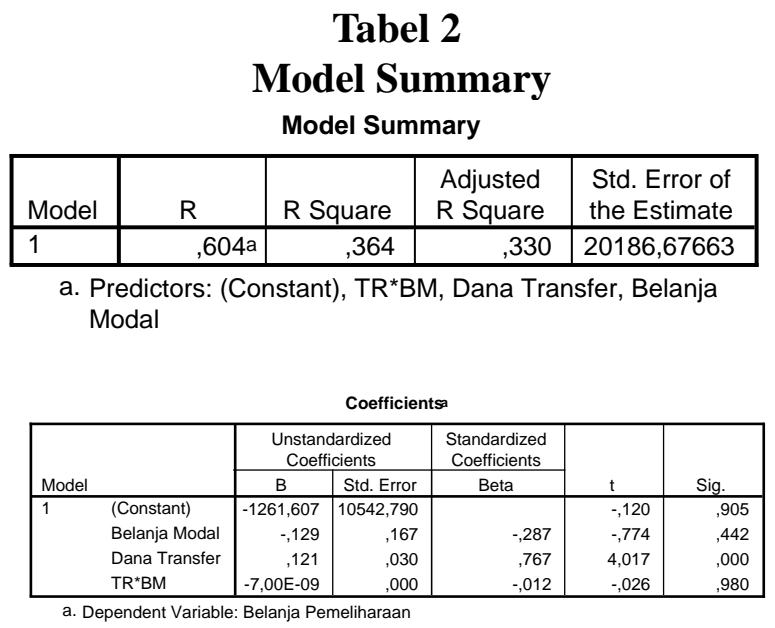

Sumber: hasil olah data

Dari tabel di atas terlihat nilai t statistic untuk varibel interaksi Pendapatan Transfer dengan Belanja Modal tidak signifikan sebesar 
0,980 sedangkan $\mathrm{t}$ statistic untuk pendapatan tranfer signifikan sebesar 0,000 . Hal ini berarti bahwa pendapatan transfer secara statistik tidak berpengaruh signifikan terhadap hubungan antara belanja modal dengan belanja pemeliharaan tahun berikutnya. Oleh karena itu, hipotesis kedua yang menyatakan pendapatan transfer berpengaruh positif terhadap hubungan antara belanja modal tahun berjalan dengan belanja pemeliharaan tahun berikutnya ditolak. Dengan demikian, kaitan kebijakan pengalokasian belanja pemeliharaan dengan belanja modal tidak dapat dilihat dari sumber pembiayaan yang berasal dari dana transfer. Artinya kebijakan pengalokasian belanja pemeliharaan tidak dapat dikaitkan dengan apakah belanja pemeliharaan tersebut dimaksudkan untuk memelihara aset yang telah ada.

Pemerintah Daerah cenderung menganggap bahwa pendapatan transfer adalah sumber dana cuma-cuma yang tidak perlu dipertimbangkan dalam penentuan anggaran belanja pemeliharaan terkait dengan kebijakan anggaran belanja modal yang telah ditentukan. Anggaran belanja modal memiliki konsekuensi diperolehnya aset tetap pada saat belanja tersebut direalisasi sepenuhnya. Hal ini berarti adanya penambahan aset tetap yang dimiliki oleh pemerintah daerah. Untuk dapat digunakan secara efektif diperlukan biaya pemeliharaan secara rutin atau terjadi berulang-ulang setiap tahun (recurrent) atas aset tetap yang dimiliki oleh pemerintah daerah. Namun karena regulasi yang berlaku di pemerintahan daerah di Indonesia, yang mengatur tentang pengelolaan keuangan dan anggaran daerah, setiap realisasi atas kebijakan yang berhubungan dengan cost atau belanja (expenditure) harus disyahkan oleh legislatif yang tertuang dalam peraturan daerah (Perda). Perda tentang anggaran daerah merupakan penentu boleh tidaknya dilakukan pengeluaran dana, termasuk biaya untuk memperoleh aset tetap (belanja modal) dan biaya untuk memelihara aset tetap tersebut. Dalam hal ini aspek politik berperan besar dalam pengalokasian anggaran belanja modal sehingga menghambat daerah dalam meyusun anggaran secara tepat (Keefer \& Khemani, 2004).

Selama ini daerah cenderung menganggap bahwa setiap transfer dari pusat pada dasarnya merupakan sedekah yang sebenarnya tidak diperlukan pemerintah daerah, jika mereka tidak terlalu boros dalam pengeluaran dan lebih tekun menarik pajak dari penduduknya. Akibatnya dalam penggunannya, kadang-kadang daerah cenderung memanfaatkan pendapatan transfer tersebut untuk tujuan-tujuan yang sebenarnya tidak diperlukan daerahnya. Artinya dalam pembuatan keputusan belanja modal yang pendanaannya bersumber dari pendapatan transfer tidak dipertimbangkan/diperhitungkan anggaran belanja pemeliharaannya.

Berbagai penegasan di atas relevan dengan apa yang dikemukan Smith (1985) bahwa persoalan keuangan daerah tidak bisa dipisahkan dari politik, baik dalam arti idiologi maupun dampak deferensial kebijakan fiskal terhadap kepentingan berbagai kelompok masyarakat yang berbeda. Lebih spesifik lagi, Pratikno (2002) menegaskan APBD merupakan kebijakan politik paling mendasar dalam penyelenggaraan pemerintahan di daerah. Melalui kebijakan ini para pembuat keputusan dapat menentukan siapa atau masyarakat mana yang lebih diuntungkan dibandingkan kelompok masyarakat lainnya (Pratikno, 2002). Sejauh mana keputusan tentang who gets what ini diambil, akan sangat tergantung pada persoalan krusial bagaimana keputusan itu dibuat, siapa yang terlibat, apa kepentingnya dan bagaimana distribusi kekuasaan di antara aktor yang terlibat tersebut. Penegasan serupa dikemukan Grindle (1980) bahwa keputusan tentang who gets what ini, akan sangat dipengaruhi oleh persoalan krusial tentang strategi, sumberdaya dan posisi kekuasaan dari masing-masing aktor yang terlibat itu sendiri (Grindle, 1980). 


\section{KESIMPULAN DAN SARAN}

\section{Kesimpulan}

Penelitian ini bertujuan pertama untuk menguji secara empiris apakah pendapatan asli daerah mempengaruhi hubungan antara belanja modal dengan anggaran pemeliharaan di anggaran pemerintah daerah. Kedua, untuk menguji secara empiris apakah pendapatan transfer mempengaruhi hubungan antara belanja modal dengan anggaran pemeliharaan di anggaran pemerintah daerah.

Penelitian yang menguji pengaruh belanja modal terhadap belanja pemeliharaan telah banyak dilakukan. Namun menunjukkan hasil yang tidak dapat disimpulkan secara konklusif dan terjadi kontradiksi antara satu peneliti dengan peneliti yang lain. Penelitian ini mencoba menganalisis pengaruh belanja modal terhadap belanja pemeliharaan dalam anggaran pemerintah daerah dengan menggunakan variabel pendapatan asli daerah dan pendapatan transfer sebagai variabel pemoderasi. Terdapat dua hipotesis yang diajukan dalam penelitian ini, pertama hipotesis untuk menguji apakan pendapatan asli daerah berpengaruh terhadap hubungan antara belanja modal dan belanja pemeliharaan. Kedua, hipotesis untuk menguji apakan pendapatan transfer berpengaruh terhadap hubungan antara belanja modal dan belanja pemeliharaan.

Hasil dari pengujian yang telah dilakukan dapat disimpulkan sebagai berikut:

Pengujian hipostesis pertama yang menyatakan pendapatan asli daerah berpengaruh terhadap hubungan antara belanja modal tahun berjalan dengan belanja pemeliharaan tahun berikutnya menunjukkan hasil bahwa hipotesis tersebut tidak dapat ditolak. Artinya pendapatan asli daerah berpengaruh positif signifikan terhadap hubungan antara belanja modal tahun berjalan dengan belanja pemeliharaan tahun berikutnya. Hasil ini menunjukkan bahwa pendapatan asli daerah merupakan variabel yang dipertimbangkan oleh pemerintah daerah pada saat menyusun besaran anggaran pemeliharaan terkait dengan kebijakan belanja modal yang telah ditentukan.

Pengujian hipotesis kedua yang menyatakan pendapatan transfer berpengaruh terhadap hubungan antara belanja modal tahun berjalan dengan belanja pemeliharaan tahun berikutnya menunjukkan hasil bahwa hipotesis tersebut ditolak. Artinya pendapatan transfer tidak berpengaruh signifikan terhadap hubungan antara belanja modal tahun berjalan dengan belanja pemeliharaan tahun berikutnya. Hasil ini menunjukkan bahwa pendapatan transfer bukan merupakan variabel yang turut dipertimbangkan oleh pemerintah daerah dalam penentuan besaran belanja pemeliharaan tahun berikutnya terkait dengan besaran belanja modal tahun berjalan.

\section{Keterabatasan dan Saran}

Penelitian ini memiliki beberapa keterabatasan yang perlu revisi terlebih dahulu untuk penelitian berikutnya. Keterbatasan tersebut di antaranya adalah sebagai berikut:

Analisis dalam studi ini menggunakan data lag untuk 1 tahun sehingga belum bisa dilakukan analisis yang lebih komprehensif. Artinya diasumsikan bahwa pengaruh belanja modal tahun terhadap belanja pemeliharaan terjadi pada satu tahun berikutnya.

Tidak mempertimbangkan sisi efektivitas dan efisiensi dalam penggunaan anggaran. Misal tidak mempertimbangkan jumlah ketersediaan dana yang ada.

Penelitian ini tidak membedakan data yang berasal dari kabupaten dan kota sehingga tidak sepenuhnya dapat dijadikan landasan untuk membuat generalisasi khusus untuk kabupaten dan kota, sebab kabupaten dan kota memiliki karakteristik yang berbeda. Penelitian berikutnya dapat membedakan antara kabupaten dan kota.

Penelitian ini menggunakan data sekunder yang diperoleh dari Laporan Realisasi APBD. Karena itu, proksi perilaku pengalokasian 
anggaran di pemerintahan daerah kabupaten/kota belum dapat tergambar dengan baik, sehingga dibutuhkan pendekatan lain yang lebih tepat untuk dapat mengetahui perilaku pengalokasian anggaran pemerintah daerah.

Saran yang dapat digunakan untuk penelitian selanjutnya yaitu:

Penggunaan data dengan periode pengamatan yang lebih panjang sehingga analisis dapat dilakukan dengan lebih komprehensip.

Penelitian selanjutnya dapat membedakan perilaku alokasi penganggaran untuk kabupaten dan kota.

Penelitian berikutnya dapat menggunakan variabel lain sebagai variabel pemoderasi yang diduga berpengaruh terhadap hubungan antara belanja modal dengan belanja pemeliharaan. Misalnya tingkat kemandirian daerah. Semakin mandiri pemerintah daerah maka pemerintah daerah akan dapat menjalankan rumah tangganya secara mandiri dalam upaya meningkatkan pelayanan publiknya. Oleh karena itu, pemerintah daerah akan semakin logis dalam menyusun anggaran belanja daerahnya.

Bagi pemerintah daerah, hasil penelitian ini menunjukkan masih lemahnya pemahaman sember daya manusia di tingkat pemerintah daerah dalam proses penganggaran khususnya dalam pengalokasian belanja pemeliharaan. Untuk itu perlu adanya penjelasan dan pengarahan yang lebih mendalam agar proses penganggaran dapat berjalan sesuai dengan yang diharapkan. Sehingga dalam pengambilan keputusan pengalokasian anggaran belanja modal sesuai dengan belanja pemeliharaan tahun berjalan dan tahun-tahun selanjutnya. Bagi pemerintah pusat, hal ini bisa ditindaklanjuti dengan mengeluarkan peraturan terkait dengan sistem penganggaran tersebut. Peraturan tersebut dapat berupa pemberian pedoman yang jelas dalam bidang pengelolaan keuangan daerah.

\section{DAFTAR PUSTAKA}

Aaberge, Rolf \& Audun Langorgen. 1997. Fiscal and Spending Behavior of LocalGovernment: An empirical analysis based on Norwegian data. Statistics Norway, Discussion paper no. 196.

Abdullah, Syukriy. 2004. Perilaku Oportunistik Legislatif Dalam Penganggaran Daerah: Pendekatan Principal-Agent Theory. Makalah Disajikan Pada Seminar Antarbangsa Di Universitas Bengkulu, Bengkulu, 4-5 Oktober 2004.

Abdullah, Syukriy \& Abdul Halim. 2004. Pengaruh pendapatan transfer(DAU) dan Pendapatan Asli Daerah (PAD) Terhadap Belanja Pemerintah Daerah: Studi Kasus Kabupaten/Kota Di Jawa Dan Bali. Jurnal Ekonomi 13 (2): 90109.

Abdullah, Syukriy \& Jhon Andra Asmara. 2006. Perilaku Oportunistik Legislatif Dalam Penganggaran Daerah: Bukti Empiris Atas Aplikasi Agency Theory Di Sektor Publik. Kertas Kerja.

Abdullah, Syukriy \& Mochammad Solichin. 2007. Pengalokasian Belanja Fisik Dalam Anggaran Pemerintah Daerah Srudi Empiris Atas Determinan dan Konsekuensinya terhadap Belanja Pemeliharaan. Jurnal Kompak Volume 13 Nomor 2.

Abimanyu, Anggito. 2005. Format Anggaran Terpadu Menghilangkan Tumpang Tindih. Bapekki Depkeu.

Ablo, Emmanuel \& Ritva Reinikka. 1998. Do Budget Really Matter? Evidence From Public Spending On Education And Health Care In Uganda. World Bank, Policy Research Paper 1926. 
Allen, Richard \& Daniel Tommasi. 2001. Managing Public Expenditure: A Reference Bookfor Transition Countries. Paris: SIGMA-OECD. http://www.oecd. org/puma/sigmaweb.

Andersson, Lars. 2002. The effect of Swedish local public expenditure of a Change in Swedish intergovernmental grant system. University of Lund, Working paper.

Aziz, Mariam Abdul, Muzafar Shah Habubullah, W.N.W. Azman-Saini, \& M.Azali. 2000. The causal relationship between tax revenues and Government spending in Malaysia. University Putra Malaysia, working Paper.

Bastian, Indra dan Gatot Supriyanto. 2003. Sistem Akuntansi Sektor Publik Konsep untuk Pemerintah Daerah, Jakarta, Salemba Empat.

Bland, Robert \& Samuel Nunn. 1992. The Impact Of Capital Spending On Municipal Operating Budgets. Public Budgeting \& Finance (Summer): 32-47.

Coate, 1981. The Case For A National Capital Budget. Public Budgeting \& Finance (Winter): 21-26.

Halim, Abdul. 2004. Akuntansi Sektor Publik Akuntansi Keuangan Daerah, Jakarta, Salemba Empat.

Indriantoro, Nur dan Bambang Supomo. 1999. Metodologi Penelitian Bisnis Untuk Akuntansi dan Manajemen. Edisi Pertama. Yogyakarta. BPFE.

Kamensky, John M. 1984. Budgeting For State And Local Infrastructure: Developing A Strategy. Public Budgeting And Finance (Autumn): 3-17.
Karo-Karo, Syukur Selamat. 2006. Hubungan Belanja Modal Dengan Belanja Operasional Dan Pemeliharaan Pada Pemerintah Kabupaten/Kota Di Pulau Jawa. Program Magister Sains - Sekolah Pascasarjana Universitas Gadjah Mada. Tesis (Tidak Dipublikasikan).

Keefer, Philip \& Stuti Khemani. 2003. The Political Economy Of Public Expenditures. Background Paper For WDR 2004: Making Service Work For Poor People. The World Bank.

Keefer,Philip\& Stuti Khemani. 2004. Democracy, Public Expenditure And The Poor. World Bank Research Observer (Forthcoming).

Mardiasmo. 2002. Otonomi dan Manajemen keuangan Daerah. Penerbit ANDI, Yogyakarta.

Mauro, Paolo. 1998. Corruption and the Composition of Goverment Expenditure. Journal of Public Economics 69: 263279.

Moisio, Antti. 2002. Essays on Finish Municipal Finance and Intergovernmental Grants. Helsinki: Government Institute for Economic Research. http://vatt.fi.

Mueller, Bernardo \& Carlos Pereira. 2003. Democratic Governance And Budget Allocation In Latin America: Electoral Rules And Legislative OrganizationTwo Complementary Dimension Of The Cost Of Governing. Universidade De Brasilia \& University Of Oxford, Working Paper.

Pagano, Michael. 1984. Notes on capital budgeting. Public Budgeting \& Finance 4 (Autum): 31-40. 
Pratikno, 2002, Keuangan Daerah: Manajemen dan Kebijakan, MAP-UGM:Yogyakarta.

Purwoko. 1999. Kajian Tentang Peranan DAU Sebagai Salah Satu Sumber Pembiayaan Daerah Otonom. www.fiskal.depkeu. go.id/bkf/kajian/

Smith, Robert W. \& Mark Bertozzi. 1998. Principal and agents: An explanatory model of public budgeting. Journal of Public Budgeting, Accounting and Financial Management (Fall): 325-353.
Thibadoux, Greg M. 1988. Capital Budgeting, In Apostolou, Nicholas G. \& D. Larry Crumbley. 1988. Handbook Of Governmental Accounting And Finance. New York: John Wiley \& Sons.

Thomassen, Henry. 1990. Capital Budgeting For A State. Public Budgeting \& Finance 10 (Winter):72-86. 